\title{
The Pattern \& Mechanism of Community Involvement in Preventing Radicalism \& Terrorism (Study Case in Central Java Province, Indonesia)
}

\author{
F V Indraswari ${ }^{1}$, W M Wiswayana ${ }^{2}$ \\ ${ }^{1,2}$ Universitas Brawijaya, Malang \\ ${ }^{1}$ fv.indraswari@ub.ac.id, ${ }^{2}$ wishnu.mahendra@ub.ac.id
}

\begin{abstract}
This paper aimed to describe and explained the pattern and mechanism of some religion communities, literature community, art community, and ex-terrorist community in Central Java Province to prevent radicalism and terrorism. The method used in this research was qualitative, which focused on interviewed the leaders of the community. They are Gema Salam Foundation, Fatayat Nahdlatul Ulama (NU) Solo, Fatayat Nahdlatul Ulama (NU) Karanganyar, Muslimat NU Karanganyar, Nasyatul Aisyiyah Solo, Perpustakaan Keliling Karanganyar, and Pintu Community. The results of this study showed that the preventing mechanism divided into two categories. The first one was building a communication and a prevention among some of them. The second one was building a confidence among Gema Salam Foundation, the local government, and the local police department. Unfortunately, these seven actors have not been connected to each other in the same forum or the same activity. This is actually strategic considering that they are represent the only ex-terrorist node in Central Java, the largest religious-based mass node in Central Java, and literacy movers with the potential of extensive networks nationally and internationally. If communication is well established, then preventive efforts will be comprehensive in its implementation
\end{abstract}

Keywords: Central Java, Community, Prevention, Radicalism, Terrorism

\section{INTRODUCTION}

Radicalism and terrorism are a sequence of violence that connected in an extreme way. The implementation of radical mindset is a physical action and tend to use a violence means which known with terrorism term. Radicalism doesn't associated with a certain religion entity. According to Omar Ashour, radicalism has a long process to reach a violence action, started from mindset into physical action [1]. Furthermore, Manni Crone believed that radicalization is an intellectual process that couldn't happen in an instant period. A process started when a person accepted extreme ideas. Then it growth with an environment that highlight the discourse of the radicalism, either in a positive or negative perspectives. A brainwash process by radicals also other potential method to develop a radical mindset. The doctrine of ideology, certain religion value could become the first step of radicalization process. In the next step, a consistent doctrine could bring the person from a mindset process into an action process. He/she will started to talk rude toward others, then he/she could easily threat and hurt others. The next level categorized with violence ways such as damaging, destroying, and even taking lives of 
certain target [2]. These violence ways which designed systematically to create an extreme fear, targeting vital victim, civilian, symbolic representative, or even random attack were a characteristic of terrorism that different it with other conflict [3].

The issue of radicalism and terrorism in Indonesia still need a wider idea and various mechanism to deal with it. The social media contribute to flourish the radicalism idea through a partial understanding toward the content. Mubarak said that a misunderstanding of 'Jihad' term nowadays has changed from a meaning of struggle against self-carnality, into an action of destroying and murdering everything related to the West [4]. This example of judgement has spread in a several provinces and cities. The central government has tracked 12 cities in Indonesia that exposed with radicalism and terrorism activity [5].

Solo is one city among 12 cities that get a red label of these two activities. Solo placed in Central Java Province. The Central Java Chief of Counter Terrorism Coordination Forum (FKPT) said that Solo is the only city in Central java that labeled with red zone, meanwhile Banjarnegara and Banyumas categorized with yellow zone [6]. Solo not only identified with zone of terrorism attack, but also with the growth of terrorism network [7] [8]. The central government and the local government already try to counter terrorism and radicalism through various policy. In 2017, The National Counterterrorism Agency (BNPT) and the local government of Central Java made a poverty alleviation program through funding for house reconstruction [9]. Based on de-radicalization program, BNPT also gave 15 ex-terrorist a training to processing and marketing fish in 2018 [10]. The local community also try to contribute toward prevention of these issues. Based on The Centre for Strategic and International Studies (CSIS) and Wahid Foundation report, Nasyiatul Aisyiyah (NA) and Fatayat Nahdlatul Ulama Solo, already made an initiative to prevent radicalism. These two religion organizations giving assistance toward women who became the victim of sexual harassment, domestic violence, and terrorism [11]. Based on this report, the women community in this province has a potential role in solving radicalism and terrorism. There's another information that showed a community response toward these two issues. From the incident of bombing in Bethel Injil Sepenuh Church (GBIS), there were some art and culture communities gathered to condemn the terrorist action [12].

This research aim to identify the further role of these communities toward prevention of radicalism and terrorism. Specifically, the pattern and the mechanism of these communities involvement. The unique condition in this province which has a huge network of public communities and ex-terrorist communities hopefully could contribute a new method of prevent and counter terrorism in a grassroots level. Finding a new mechanism that comes from the need of those communities to provide security and harmonization among the society could be a proper way to tackle the spread of radical ideas.

\section{RESEARCH METHOD}

The method used in this research was qualitative, which focused on interviewed the leaders of the community. They are Gema Salam Foundation, Fatayat Nahdlatul Ulama (NU) Solo, Fatayat Nahdlatul Ulama (NU) Karanganyar, Muslimat NU Karanganyar, Nasyatul Aisyiyah Solo, Perpustakaan Keliling Karanganyar, and Pintu Community. Gema Salam Foundation is the ex-terrorist community. Meanwhile Fatayat NU, Muslimat NU, Nasyatul Aisyiyah represent the biggest and well known women religion communities. Perpustakaan keliling is the community that focus on spreading literacy awareness. Pintu Community is one of the art and culture community in Solo. All the primary data from the interview was also supported with the secondary data from official documents, academic papers, reports, and 
dataset. The analysis of the data using Miles \& Huberman guideline which started from data condensation, data display, conclusion and verification [13].

\section{RESULT AND DISCUSSION}

Radicalism discourse started to grow in Europe after the Belgic Police Department and its National Intelligence Agency analysis the potential of terrorist action from the radical behavior of young migrants, especially from Morocco's diaspora. This assessment spread to the Dutch Police Department and supported by the trend of recruitment of young Dutch's by the Moslem fundamentalist. Rik Coolsaet found the process of radicalism in a process of individual's decision to participate or support Jihad movement abroad. He then give a definition of radicalization as a part of recruitment which lead by a foreigner and has an aim to driver the certain targets to joint in the campaign of terrorist action abroad [14]. He also found various motives such as social marginalization, exclusion, political motive, and ideological motive as a potential background of radicalization. Coolsaet criticized the ideological motive in some policy studies, law enforcement, and in academicals discourse. The dominant discourse of this motive neglected other motives that could also bring by the extremist. And its growth in the West society along with the immigration, integration, and Islam issues in 1970s. Coolsaet perspective toward radicalization has a similar explanation with Manni Crone. Crone agree with the process of indoctrinate the ideology or religion value that could lead to radicalization. In a different way, Crone saw that radicalization could happen in a local level or domestically. This condition bring up a new concept called 'homegrown terrorism'. This local terrorism found in some pattern such as a terrorist who come from the same city of the terrorist attack. They were born and grow up in that city, so there's a small potential assumption that radicalism could influence them. They also lived in a democratic, comfort and peace environment [2] From this identification, Crone invite everyone to analyze more on the behavior radicalization than the ideological radicalization per se. The Danish Institute for International Studies (DIIS), from the total of terrorist amount in Europe since 2012-2015, 80\% of those terrorists already had a criminal record before and $60 \%$ of them had been jailed [15]. From this data, Crone analyze that terrorist action could be happen from a chain of difficulty and violence experience that face by the perpetrator. The Organization for Security and Co-operation in Europe (OSCE) also give a concern related to the correlation of radicalism and terrorism. There's also a specific term toward this study named 'Violent extremism and radicalization that lead to terrorism' (VERLT). The radicalism that lead to terrorism defined as a dynamic process which a person accepted terrorist violence as something acceptable or even giving legitimation toward the action. This process may enable the individual to support or even engage in terrorism [16].

Central Java Province has experience with terrorist attack since 1997. According to National Consortium for the Study of Terrorism and Responses to Terrorism (START), there are 18 of terrorist attacks from 1997 until 2017. The attack found in 15 cities/districts from 35 of total cities/districts in Central Java Province. There are Ambara, Banyumas, Binangun, Magelang, Pahlawan, Pekalongan, Tegalrejo, Purbalingga, Semarang, Sigaluh, Sidareja, Sukoharo, Surakarta, Surakarta (Solo), Tlepok, and Wonosobo [17].

The spread of terrorism accident, has a dynamic frequency for 20 years $(1997-2017)$. The increase of the attack found around $2011-2013$ and from 2015-2017. In the other side, the lowest incident identified since $1999-2011$ and from $2013-2015$. The terror has a various pattern and different target in a certain period. In the end of 90 s, the type of the attack was a mass attack. The riot of political condition in Jakarta influence the stability in these cities. At that time, Indonesia face a climax situation of reformation. A huge mass of college students 
and a large mass of community groups, united, demonstrated and occupied the parliament building demand for a presidential change and a total reformation toward political system and economic recovery. In 2000s, the movement of terrorist group with a religion background dominated the attacks [17] .

The form of attack has a huge damage and targeting civilians. There's a suicide bomb in Bethel Injil Sepenuh Church (GBIS), in Kepunton, Solo, on September 25, 2011. In the next year, there were three other accidents in Surakarta with a target of police post and police office. The type of the attack was throwing explosives and shooting the police officer. The terrorist use motorcycle to attack the police post and police office. The victim of the terrorist attack not only from the police officer, but also from civilians. START has four categories of terrorist attack. They are armed assault, bombing/explosion, facility/infrastructure attack, and unknown categories [17].

All the attacks in 20s, comes from various factors. Argyo Demartoto said that Solo city become the most comfortable place for a development of ideology for radical group or terrorism. He analyzed it from the arrested of terrorist suspects in Bengawan. Moreover, Noor Huda Ismail, a terroris analyst said that Solo become a safe based for a certain groups such us Laskar Umat Solo (LUIS), tim Hisbah, Forum Komunikasi Aktivis Masjid (FKAM), Front Perjuangan Islam Solo (FPIS), Majelis Tafsir Alquran (MTA), MMI Solo, HTI, JI, JAT, and others. They move together in response Islamic issues. They have a huge partisan [18]. The last two organization has a strong basis in Solo and known as an icon for jihad movement and as a resistance symbol that get a support from their member and participant. The attack also trigger by a friction among the different groups from various religion, ethnic, and ideology. A friction between those groups and the passive response of local government also built a negative relationship among them[19].

The central government through BNPT already made various program to prevent and counter radicalism and terrorism in Central Java Province. In August 2018, there was a socialization of anti-terrorism in six private colleges around Central Java [20]. A month later, BNPT signed a Memorandum of Understanding (MoU) with Semarang National University (UNS), Diponegoro University (UNDIP), 17 Agustus Semarang University (UNTAG), Polytechnic of Health Kemenkes Semarang (POLTEKKES Semarang), Polytechnic of Maritime Negeri Indonesia Semarang, and National Polytechnic of Semarang [21]. The MoU cover the activity such as education, training, study, research, community service, and institution development to support counterterrorism effort. There's also a collaboration program with the stakeholders in local department. There's an integrative mitigation training to counter terrorism in November 2018. The training aimed to build an alertness in vital object of the province, such as an airport. Its also aimed to integrate the comprehensive standard operation to mitigate the potential of terrorist attack [22].

The effort of local government of Central Java also could be found around 2018. The Governor of Central Java Province stated that the civil staff that exposed with radicalism will be given discipliner action such as clarification and rehabilitation to bring back the loyalty toward Pancasila, Bhinneka Tunggal Ika, and Undang-Undang Dasar 1954 as the basic value of Indonesia [23]. The Vice Governor of Central Java also approach the Moslem groups and asking the religious leader in Central Java to not give up and never stop to spread peace through the Islamic value 'rahmatan lil 'alamin' (be a mercy to the universe) [24]. The Police Department in Central Java level focused on de-radicalization program, rehabilitation program, and law enforcement toward the ex-terrorist [25]. This department also made a cooperation with the National Army of Indonesia (TNI) and the Government of Central Java Province by 
signed a MoU in 2018 to arrange the cooperation handbook to preserve public security and stability [26].

Beside the central government and the local government, there are other component in society that also taking important role to prevent and counter radicalism and terrorism. Henry Shaftoe said that the society component in the sub-national level inside the state also taking strategic role in escort and embrace each other. These society components such as police, priests, imam's, community development workers, social workers, urban designers \& planners, community safety officers, housing staff, youth workers, and teachers could response faster than the national government toward terrorist attack. They are categorize in three groups such as regional government, religious institutions, and voluntary organizations. They could manage the crisis condition through cultural and religion media. Their involvement could be a bridge in dealing with inequality issues, marginalization, and injustice from the state . Esposito, Aris and Calfa give a further concept to prevent terrorism in sub-national level. The concept taking from a series of case study in the city of Great Britain, Portugal, Poland, and Germany. They are four indicators to prevent terrorism in local level. The first one is preventive and communication action. The second one is crisis management action. Its followed with confidence building measures. The fourth indicator is supporting the victim [27].

To give more specific explanation, Hussein Tahiri \& Michele Grossman agree that all community, either moslem or non moslem, take a key role in preventing and mitigating the threat of violence from the extremist [28]. OSCE also agree with the strategic role of community. A civil society has a capability and experience in implementing the program that support a peace and an inclusive society. They could reduce a complex social structure that could lead to violence and extremist. Their efforts often reach a grassroots' level in social interaction which contribute to an easier access to enter inside the society. The trusted community has a legitimation and influence in their environment [16].

There are more than 150 communities in Central Java. There's 113 communities which various from sport communities, social communities, religion communities, and other variant [29]. There's also 54 belief communities spread in Central Java [30]. They are different with religion communities. They have their own value and it's used to be practiced since a long time ago until now. There's also 5.850 Islamic Boarding School in this province [31]. Central Java also known as the province with multi religions live peacefully. From this number we can see that certain cities such as Solo/ Surakarta, Semarang, Magelang with the huge number of those communities could be a potential target of radicalism and terrorism.

From all those communities, we choose seven communities that represented religion community, ex-terrorist community, social community, and culture community. We try to identify their role in preventing and counter radicalism and terrorism in their society. The first one is Gema Salam foundation which consist of ex-terrorist. From the interview with the leader of the community, he said that the community focused on giving assistance toward their fellow that still in prison. He and other ex-terrorist member that already released from the jail, has a routine visit to give motivation and slowly asked them to change their wrong mindset. This community also support the member to socialize with the society by being entrepreneurship. There are 40 active member that lives in Yogyakarta, Surakarta, and other cities in Central Java Province. The field of business such as automotive workshop, steak restaurant, small food stall, laundry service, and others [32]. Their focus on social and economic sector showed that they want to give more contribution in a real form. It's another form of contribution toward society that represent in a peace way. The support from the government also a form of state representation to protect their citizen's basic right and also to prevent them to return in any kind of radicalism and terrorism. 
Most of the ex-terrorist got a social and economic assistancy from the national government such as Social Ministry and National Counter Terrorism Agency (BNPT). These national goverment representatives also build cooperation with local government in a level of Central Java Province such as Penitentiary Agency, Social Services Agency, Terrorism Prevention Communication Forum (FKPT), National Unity and Politics Agency (Kesbangpol) They gave them some capital such as fresh money, a stall with basic needs to sell, animals (e.g. a sheep) as a livestock. The assistancy for lives not only give to the ex-terrorist but also to their family -wife and children-. The committment from assistancy could be trace since 2015-now (2019) [33]-[38].

The second community that we've been interviewed is Fatayat Nahdlatul Ulama (NU) Solo. Fatayat NU is the women subdivision from of the biggest Islamic organization in Indonesia, Nahdlatul Ulama (NU). It has branches from the main of capital city of the state until the level of village. In Solo, Fatayat NU have tried to build a communication toward the wife of ex-terrorist. This is based on their commitment to provide protection for women and children. Since 2018, the leader of Fatayat NU Solo said that they already try to open communication and interaction toward the wife of ex-terrorist through one of the ex-terrorist. Unfortunately, there's still no response from them until this interview was conducted. The head of Fatayat NU Solo aware that this meeting is strategic because of the important role of women in building a character of their children and family comprehensively. The meeting supposed to start an understanding process of social, economic, and psychological condition from the wife of ex-terrorist. She hope the first meeting will be followed by another routine meeting to give a sustainable assistance.

Fatayat NU Solo also build a connection with other communities in Solo and known as Cross Cultural Network (JLK). This network consist of the leader of various religion in Indonesia and other Head of communities in Solo. They build a system of communication by using WhatsApp group. In this group, they could made such an early warning system to prevent a potential radicals or terrorist activity. They update the condition in their society to prevent from provoked issues that could bring to violence action. This communication also reduce a negative stigma toward certain community that used to be labeled as an anarchist and radical community.

In internal organization, the prevention efforts done by educating the member and the participant with their own value. There are four basic society behavior values which became the basic guideline for the member and participant. The first and the second one is At-Tawassuth and I'tidal. At-Tawassuth means 'in the middle', take the proportional way or decision. I'tidal means take a justice principle in making decision, impartiality. The second one is Tasamuh or being tolerance, respect the difference and respect to other's principle which may different from us. The third one is Tawazun which means balance, not overwork toward everyone, every relation, everything in individual and also social life. The fourth is called Amar Ma'ruf Nahi Munkar means supporting every good behavior and reject avoid, and prevent every little things that could lower life values. All the values implemented through seven aspects such as in faith, in law, in morality, in inter group relations, in nation life, in culture and in dakwah [39]. These value also reviewed in every leadership program from a structural member. According to the Head of Fatayat NU Solo, the value has a similarity with the workshop's material that they've been received from National Counter Terrorism Agency related to preventing radicalism and terrorism.

These four basic values also confirmed by the Head of Fatayat NU Karanganyar, as the third community that we've been interviewed. They put the values in their economic empowerment program. They support the women in their environment with preparing to build 
cooperative unit, a herbal drinking production, a Women Farmer Group. They also prepare the society with skill of technology such as an information of technology workshop and design workshop. Beside that there's a program of giving socialization to the society about the awareness to prevent the spread of incorrect or invalid news by using social media [40].

Muslimat NU Karanganyar is the fourth community that showed similarity with two previous communities. As they are under the same main organization, the basic values and its education process toward their member and follower also done in the same mechanism. The movement of Muslimat NU Karanganyar is not as various as Fatayat NU, and tend to use conventional way of empowering women in the society. This is because the segment of member and participant of Muslimat NU is older than the Fatayat NU. Muslimat NU is for the age of 40 years old and over it. Meanwhile, Fatayat NU is focused on children from 3 years old to 30s years old. The Muslimat NU Karanganyar focus on giving religious knowledge and understanding in a routine meeting at least once a weak.

The fifth community is Nasyiatul Aisyiyah Solo. This is the women branch of Muhammadiyah, another biggest Islamic organization in Indonesia. It's also has a huge number of member and follower all around Indonesia. In Solo, the Head of Nasyiatul Aisyiyah Solo also focus on women empowerment. This community has a track record of giving psychological assistance toward the family of terrorist suspect in 2016. At that time, Siyono, one of Cawas, Klaten citizen arrested by Detachment 88 and suspected as a terrorist. In the end, the accusation was not proven but Siyono was found dead during the process of detention. The unclear explanation from the authority officer made the people of Solo city angry and demonstrate in the street to sue for justice. Siyono left his wife and children. This condition also one of the fragile condition that could bring to a potential change from a sense of injustice to the feeling of revenge in an extreme one. Nasyiatul Aisyiyah aware of this and directly visiting the wife and the children of Siyono to give them understanding and assistance. The head of Nasyiatul Aisyiyah said that it wasn't easy in the first meeting. But after a periodic visiting and assistance, the life of Siyono's wife and children slowly better. This assistance toward women and children match with the basic program of this community [41].

Perpustakaan Keliling Karanganyar is a non-religion community in Central Java Province. It's a community that concern in giving literacy education through books that they posted regularly in view spots around Karanganyar. The main target of this activity is children who start learn to read and mostly in a school years. In the context of preventing radicalism and terrorism, they have a specific strategy to prevent the children from radical or extreme content of books. First, the book that they collected from the donator was selected. They check the content one by one. If the book doesn't consist of radicalism or extreme narrative, then the book passed to read by the children. They ever found some children books that already consist of radicals tension, and it's make them alert toward any content of the book. Beside giving a facility of public place to read, they also give education to the children about nationalism, universal values, and counter intolerance mindset toward story telling or a simple socialization.

The Pintu Community is an art and culture community in Solo. This community try to become a bridge between the ex-terrorist community with the other communities in Solo. The target of this community is to keep a stability condition in Solo as a tolerance and a nonviolence city in Indonesia. The program arise mostly after several incident of terrorism and radicalism activity in Solo and around it .

Based on Esposito, Aris and Calfa conception toward the pattern and mechanism of community to prevent terrorism, all the communities above had a specific characteristic and pattern. The religion community such as Fatayat NU Solo, Fatayat NU Karanganyar, Muslimat NU Karanganyar, and Nasyiatul Aisyiyah Solo showed that they had internal values that keep 
their member, follower and the society around them from the potential doctrine, or persuasive act of radicalism and terrorism. This value was repeated in every meeting and leadership program. So, as long as they had a strong communication, an intensive meeting toward their society, this value and their active program will support to avoid radicalism and terrorism. These religion communities has fulfill the categories of building preventive and communication actions. Specifically for Nasyiatul Aisyiyah, it's also contribute in categories of supporting victim according to Esposito explanation.

Meanwhile, for the ex-terrorist community, they seems still not attach or build communication toward religion community. They prefer to fix and support their economic life by doing some business things. This economic activity not only help them to survive, but slowly but sure, help them to get trust from the society. Their presence in social life showed that they also can be productive and give contribution to the society. Their good connection to the local government and law enforcement institution is one of an effort to build trust among them. This initiative communication and coordination also help the police department to control their movement so that could minimize the potential radicalism and terrorism activity. At this point, the Gema Salam Foundation's role include in categories of confidence building measure.

The last two communities, such as Perpustakaan Keliling Karanganyar and Pintu Community try to build a peace condition in its scope society by reaching children and art society. This soft approach may be not give a direct awareness of preventing these issues, but at least, a beginning of giving the right understanding toward radicalism and terrorism issues, and try to counter it in a local way, is very meaningful and may be more accepted by the society. For these two communities, they are classified in supporting preventive and communication actions.

Unfortunately, there's no one single network has been conducted among these seven community in the same forum that specifically talking about preventing radicalism and terrorism. Each of them move by themselves to prevent these issues. If there's an effort to build communication, the other side still not response it. Maybe there's still a prejudice, a negative stigma within their selves toward others or event toward their selves.

\section{CONCLUSIONS}

The role and pattern of community in preventing and counter radicalism and terrorism is very important. They are the one who knows better their society and the complexity of the situation. In Central Java Province, these seven communities, with their background of ideology and experiences, had tried to manage and solve these issues from the grassroots level. There's a success among their effort. For example they could build an early warning system of communication to prevent a potential negatives issues. But unfortunately, not all the community has already joint to this system. Meanwhile it's important to build an integrative and one common mechanism to prevent and mitigate these kind of issues so that the damage could be minimize and the victim won't be counted. It's also one of Esposito requirement in preventing terrorism, which is crisis management action.

For each community, it's important to take an initiative step to build communication among them. It's one of the basic effort to clear our mindset toward other and ourselves. If the mindset already clear, then the next step would be easier and more objective. An integrative method to prevent and counter this issues could be build and implemented simultaneously. The society could be protected by the vital role of communities based on confidence building measures that they build one by one. 
For the government, supporting the community to communicate and coordinate in a periodic time will also help to build a stable condition in Central Java Province. Understanding will be develop in a routine meetings. The government also helped in follow up the national agenda to counter terrorism and radicalism by the strategic roles of the community that actively build a mechanism to tackle the issues in a respective way based on local wisdom. Especially when the current issues of terrorism comes up with the trend of female bombing perpetrators which will need women's community role to prevent it.

\section{REFERENCES}

[1] O. Ashour, "Votes and Violence: Islamists and The Processes of Transformation Developments in Radicalisation and Political Violence," 2009.

[2] M. Crone, "Radicalization revisited: Violence, politics and the skills of the body," Int. Aff., vol. 92, no. 3, pp. 587-604, 2016.

[3] P. Wilkinson, "Terrorism versus democracy: The liberal state response, 2nd edition," Terror. Versus Democr. Lib. State Response, 2nd Ed., pp. 1-254, 2006.

[4] Z. Mubarak, "Fenomena Terorisme di Indonesia : Kajian Aspek Teologi, Ideologi dan Gerakan,” J. Stud. Masy. Islam, vol. 15, no. 2, pp. 240-254, 2012.

[5] Regional.kompas.com, "Ini 12 Daerah yang Masuk Zona Merah Terorisme," 2016. [Online]. Available: https://regional.kompas.com/read/2016/06/01/07410011/Ini.12.Daerah.yang.Masuk.Z ona.Merah.Terorisme. [Accessed: 15-Dec-2019].

[6] L.Zamami, "Jateng Masuk Zona Merah Penyebaran Radikalisme dan Terorisme." [Online]. Available: https://lifestyle.kompas.com/read/2018/09/10/14251871/jatengmasuk-zona-merah-penyebaran-radikalisme-dan-terorisme. [Accessed: 15-Dec-2019].

[7] D.Sinuko, "Densus 88 Tangkap Dua Terduga Teroris di Solo," 2015. [Online]. Available: $\quad$ https://www.cnnindonesia.com/nasional/20151230105954-20101132/densus-88-tangkap-dua-terduga-teroris-di-solo. [Accessed: 15-Dec-2019].

[8] Parwito, "Polda Jateng sebut Densus 88 tangkap tiga orang terduga teroris | merdeka.com," 2017. [Online]. Available: https://www.merdeka.com/peristiwa/poldajateng-sebut-densus-88-tangkap-tiga-orang-terduga-teroris.html. [Accessed: 15-Dec2019].

[9] A. Prawira, "BNPT Gandeng Pemerintah Daerah Cegah Potensi Terorisme," 2017. [Online]. Available: https://nasional.sindonews.com/read/1263647/14/bnpt-gandengpemerintah-daerah-cegah-potensi-terorisme-1512622832. [Accessed: 15-Dec-2019].

[10] A. Sunaryo, "15 Mantan Narapidana Teroris di Solo Belajar Mengolah Ikan | merdeka.com," 2018. [Online]. Available: https://www.merdeka.com/peristiwa/15mantan-narapidana-teroris-di-solo-belajar-mengolah-ikan.html. [Accessed: 15-Dec2019].

[11] A. M. Dja'far, L. Taqwa, and S. Kholisoh, "Intoleransi dan Radikalisme Di Kalangan Perempuan: Riset Lima Wilayah Di Bogor, Depok, Solo Raya, Malang, dan Sumenep," pp. 1-17, 2017.

[12] Y.Satriawan, "Komunitas Seni Budaya dan Tokoh Lintas Agama di Solo Kecam Aksi Terorisme," 2011. [Online]. Available: https://www.voaindonesia.com/a/komunitasseni-budaya-dan-tokoh-lintas-agama-di-solo-kecam-aksi-terorisme130556258/98647.html. [Accessed: 15-Dec-2019].

[13] M.B. Miles; A.M. Huberman; J.Saldana, Qualitative Data Analysis A Methods Sourcebook Ed.3, 3rd ed. California: SAGE Publication Inc., 2018. 
[14] R. Coolsaet, "All Radicalisation is Local," Brussels, 2016.

[15] www.diis.dk, "crimeplots141215 (4).".

[16] Organisation for Security and Co-operation in Europe, "Preventing Terrorism and Countering Violent Extremism and Radicalization that Lead to Terrorism: A Community-Policing Approach," Article, pp. 41-43, 2014.

[17] gtd.terrorismdata.com, "GTD 1970 - 2018 - CHC Global \& START," 2019. [Online]. Available: https://gtd.terrorismdata.com/files/gtd-1970-2018/. [Accessed: 16-Dec2019].

[18] I. Septiyaning, "Pengamat: Solo Jadi Tempat Nyaman Bagi Kelompok Radikal | Solo Solopos.com," 2012. [Online]. Available: https://www.solopos.com/pengamat-solojadi-tempat-nyaman-bagi-kelompok-radikal-357564. [Accessed: 15-Dec-2019].

[19] I. Hasani and B. T. Naipospos, Dari Radikalisme Menuju Terorisme STUDI RELASI DAN TRANSFORMASI ORGANISASI ISLAM RADIKAL DI JAWA TENGAH \& D.I. YOGYAKARTA. 2012.

[20] www.bnpt.go.id, "Wujudkan Pola Penanganan Radikalisme di Perguruan Tinggi, Kepala BNPT Berikan Sosialisasi Anti Terorisme Kepada Petinggi PTS Se-Wilayah 6 Jawa Tengah - Badan Nasional Penanggulangan Terorisme,” 2018. [Online]. Available: https://www.bnpt.go.id/wujudkan-pola-penanganan-radikalisme-di-perguruan-tinggikepala-bnpt-berikan-sosialisasi-anti-terorisme-di-hadapan-petinggi-pts-se-wilayah-6jawa-tengah.html. [Accessed: 15-Dec-2019].

[21] www.bnpt.go.id, "Dukung Penguatan Perguruan Tinggi, Kepala BNPT Tandatangani 6 MoU Sekaligus Berikan Kuliah Umum di Semarang - Badan Nasional Penanggulangan Terorisme," 2018. [Online]. Available: https://www.bnpt.go.id/dukung-penguatanperguruan-tinggi-kepala-bnpt-tandatangani-6-mou-sekaligus-berikan-kuliah-umum-disemarang.html. [Accessed: 15-Dec-2019].

[22] www.bnpt.go.id, "Kepala BNPT Menjadi Inspektur Upacara Penutupan Latihan Mitigasi Aksi Terorisme Integratif Tahun 2018 - Badan Nasional Penanggulangan Terorisme," 2018. [Online]. Available: https://www.bnpt.go.id/kepala-bnpt-menjadiinspektur-upacara-penutupan-latihan-mitigasi-aksi-terorisme-integratif-tahun2018.html. [Accessed: 15-Dec-2019].

[23] R.Belarminus, "Ganjar Pranowo Sebut Ada ASN Jawa Tengah yang Berpaham Radikal,” $2019 . \quad$ [Online]. Available: https://regional.kompas.com/read/2019/03/25/12395041/ganjar-pranowo-sebut-adaasn-jawa-tengah-yang-berpaham-radikal. [Accessed: 15-Dec-2019].

[24] jatengprov.go.id, "Sebarkan Virus Perdamaian - Pemerintah Provinsi Jawa Tengah," 2019. [Online]. Available: https://jatengprov.go.id/publik/sebarkan-virus-perdamaian/. [Accessed: 15-Dec-2019].

[25] I. S. P. Marpaung, "POLITIKA, Vol. 6, No.1, April 2015," vol. 6, no. 1, 2015.

[26] Jateng.tribunnews.com, "Gandeng TNI dan Polri, Pemprov Jateng Jaga Kondusivitas Wilayah dari Teorisme dan Radikalisme - Tribun Jateng,” 2018. [Online]. Available: https://jateng.tribunnews.com/2018/05/25/gandeng-tni-dan-polri-pemprov-jateng-jagakondusivitas-wilayah-dari-teorisme-dan-radikalisme. [Accessed: 16-Dec-2019].

[27] F. Esposito, "European Forum for Urban Safety SECUCITIES CITIES AGAINST TERRORISM TRAINING LOCAL REPRESENTATIVES IN FACING TERRORISM Written by: Frédéric Esposito With the collaboration of Justyna Kułach-Aris and Roxana Calfa," 2017.

[28] H. Tahiri and M. Grossman, "Community and Radicalisation: an Examination of Perceptions, Ideas, Beliefs and Solutions Throughout Australia," Victoria Univ., no. 
September, pp. 1-140, 2013.

[29] suaramerdeka.com, "113 Komunitas Masuk Nominasi - Suaramerdeka.com Cyber News," $2018 . \quad$ [Online]. Available: https://www.suaramerdeka.com/community/baca/84328/113-komunitas-masuknominasi. [Accessed: 15-Dec-2019].

[30] Gatra.com, "Kelompok Penghayat Kepercayaan Terbanyak Ada di Jawa Tengah | Gaya Hidup," $2019 . \quad$ [Online]. Available: https://www.gatra.com/detail/news/424523/lifestyle/kelompok-penghayatkepercayaan-terbanyak-ada-di-jawa-tengah. [Accessed: 15-Dec-2019].

[31] jateng.bps.go.id, "BPS Provinsi Jawa Tengah," 2019. [Online]. Available: https://jateng.bps.go.id/dynamictable/2019/01/23/61/banyaknya-pondok-pesantrenkyai-ustadz-dan-santri-menurut-kabupaten-kota-di-jawa-tengah-2014-2015.html. [Accessed: 15-Dec-2019].

[32] A. W. Wibowo, "40 Eks Napiter di Jateng Bangkit Merintis Usaha," 2019. [Online]. Available: https://jateng.sindonews.com/read/6516/1/40-eks-napiter-di-jateng-bangkitmerintis-usaha-1561737987. [Accessed: 15-Dec-2019].

[33] liputan6.com, "Ini Dia Bantuan Pemerintah untuk Bekas Napi Teroris - Health Liputan6.com," 2015. [Online]. Available: https://www.liputan6.com/health/read/2221958/ini-dia-bantuan-pemerintah-untukbekas-napi-teroris. [Accessed: 15-Dec-2019].

[34] L. I. . Widuri, "Kemensos Berencana Bina Napi Eks Teroris - KBK | Kantor Berita Kemanusiaan," $2016 . \quad$ [Online]. Available: http://www.kbknews.id/2016/09/21/kemensos-berencana-bina-napi-eks-teroris/. [Accessed: 15-Dec-2019].

[35] H. Arfah, "Mensos Beri Bantuan kepada Mantan Napi Terorisme," 2017. [Online]. Available: https://regional.kompas.com/read/2017/09/17/19451461/mensos-beribantuan-kepada-mantan-napi-terorisme. [Accessed: 15-Dec-2019].

[36] D. Saraswati, "Keluarga Mantan Napi Terorisme akan Dapat Perlindungan Sosial," 2018. [Online]. Available: https://www.cnnindonesia.com/nasional/2018020606495420-274100/keluarga-mantan-napi-terorisme-akan-dapat-perlindungan-sosial.

[Accessed: 15-Dec-2019].

[37] Gatra.com, "Pemberdayaan Ekonomi Penting untuk Eks Napi Teroris | Politik," 2019. [Online]. Available: https://www.gatra.com/detail/news/425053/politic/pemberdayaanekonomi-penting-untuk-eks-napi-teroris. [Accessed: 15-Dec-2019].

[38] F. Sodiq, "Gandeng BNPT, Lapas Semarang Gelar Reintegrasi Sosial Napi Teroris Ditjenpas | Membangun Pemasyarakatan Bersih dan Melayani,” 2018. [Online]. Available: $\quad \mathrm{http} / / /$ ditjenpas.go.id/gandeng-bnpt-lapas-semarang-gelar-reintegrasisosial-napi-teroris. [Accessed: 15-Dec-2019].

[39] M.Abdusshomad, "Karakter Tawassuth, Tawazun, I'tidal, dan Tasamuh dalam Aswaja," 2009. [Online]. Available: https://islam.nu.or.id/post/read/16551/karaktertawassuth-tawazun-i039tidal-dan-tasamuh-dalam-aswaja. [Accessed: 15-Dec-2019].

[40] Nu.or.id, "Momen Ramadhan, Siber NU Karanganyar Gencarkan Sedekah 'Follow' dan 'Sharing,"” 2019. [Online]. Available: https://www.nu.or.id/post/read/106482/momenramadhan-siber-nu-karanganyar-gencarkan-sedekah-follow-dan-sharing-. [Accessed: 15-Dec-2019].

[41] P.P.P.N.Aisyiyah, "TANFIDZ KEPUTUSAN MUKTAMAR NASYIATUL AISYIYAH KE XIII YOGYAKARTA, 25-28 AGUSTUS 2016,” 2016. 
